\title{
HUBUNGAN KOMPETENSI DAN BEBAN KERJA DENGAN PRESTASI KERJA GURU MILITER AKADEMI TNI
}

\author{
Elyah Musarovah ${ }^{1}$
}

\begin{abstract}
The purpose of this studyis to improve competence and standaritation of workload militery teacher in TNI Militery Academy in Magelang Central Java. The reserch metodology was survey which selected by sample random sampling technique with quesioner. Analysis and interpretation of the data indicates that (1) ability the militery teacher include indicator the competence techer with pedagogik, profesional, attitute and social, (2) workload include all of the militery teacher of the appricial performance with the compentency job and (3) job performance include indicator the quantity, quality, dicipline and attitude performance.
\end{abstract}

Keywords: competence, workload, job performance.

\section{PENDAHULUAN}

Guru tidak lagi hanya sebatas bekerja secara manual, melainkan sudah harus semakin akrab dengan instrumen teknologi informasi dan komunikasi, misalnya: komputer, internet, dan sebagainya. Hal ini dapat berimplikasi pada perubahan sikap dan prilaku guru dalam melaksanakan tugas-tugasnya. Guru sebagai pendidik adalah merupakan tenaga profesional, sebab pendidik harus memiliki kualifikasi minimum dan sertifikasi sesuai dengan jenjang kewenangannya dalam mengajar, sehat jasmani dan rohani, serta memiliki kemampuan untuk mewujudkan tujuan pendidikan nasional. Guru merupakan ujung tombak, maka tidak mudah memikul beban sebagai guru, pada kenyatannya guru dihadapkan pada permasalahan internal yang masih sangat kompleks, dibarengi tuntutan untuk memajukan pendidikan yang berbudaya dan berkarakter ditambah lagi beban kerja guru dalam menghadapi hari-harinya adalah untuk menjadi guru yang profesional, guru yang profesional harus mampu mengasuh berbagai bidang ilmu yang teridentifikasi dalam bentuk mata pelajaran.

Guru profesional adalah guru yang mampu menguraikan standar isi menjadi silabus dan mengembangkan silabus dalam rencana pembelajaran, ini menggambarkan kemampuan guru dalam mengembangkan kurikulum dilihat dari aspek dokumen. Secara real guru mengimplementasikan pembelajaran sesuai petunjuk yang tertera pada silabus dan rencana pembelajaran sehingga capaian standar tingkat kompetensi yang berupa kompetensi dasar dapat dipenuhi dengan menggunakan metode pembelajaran yang menggairahkan bagi peserta didik untuk belajar, kemampuan mengimplementasikan pembelajaran ini bagian dari pengembangan kurikulum dalam bentuk pengalaman belajar.

Guru di kalangan militer disebut dengan guru militer, guru militer dalam melaksanakan tugas pokoknya sebagai pengajar, pemimpin, pembuat model, dan manajer kelas harus mampu menyusun silabus yang mengacu pada standar isi serta menyusun rencana pembelajaran yang mengacu pada silabus dan juga dapat mengimplementasikannya dalam kegiatan belajar mengajar, artinya guru harus memahami dan menguasai dengan seksama tugas dan tanggung jawabnya secara

\footnotetext{
${ }^{1}$ Perwira Menegah Akademi TNI
} 
profesional. Guru militer harus mampu belajar merubah tingkah laku anak didiknya utamanya belajar untuk membangun makna yang dilakukan secara langsung dalam komunikasi, interaksi dan refleksi sehingga anak didiknya dapat memproduksi gagasan yang bermakna, jadi belajar untuk memproduksi gagasan bukan mengkonsumsi gagasan oleh karena itu setiap guru militer dapat memberikan kesempatan/dorongan anak didiknya untuk dapat mengungkapkan pikiran, gagasan, pendapat dan proses sehingga dapat merubah tingkah laku anak didiknya, sehingga pembelajaran yang bersifat menghafal atau role learning dalam pembelajaran yang bersifat menerima atau reception learning sebaiknya jangan lagi digunakan sehingga pengetahuan yang paling berharga adalah memampukan anak didik untuk dapat menangani berbagai masalah dan menyiapkan mereka untuk menyelesaikan berbagai masalah yang kelak akan mereka temui sebagai seorang dewasa ditengah-tengah masyarakat, "the right portion of the model contains the two primary outcomes of interest to organizaion behavior reserchs (and employees and managers in organozation): job performance and organizational commitment. Most employees have two primary goals for their working lives: to perform their jobs well and to remain a member organization that they respect."

Guru militer adalah merupakan agen perubahan dalam memberikan pendidikan akademik dan sanubari untuk membentuk manusia berkarakter di kalangan militer sehingga ditangan guru militer akan mampu mengangkat citra dan marwah setiap lembaga pendidikan dalam menyiapkan hasil didik yang berkualitas. Akan tetapi dalam menunjang keberhasilan anak didiknya tidak terlepas dari kerjasama yang baik antara setiap personel di lembaga pendidikan dalam semua bidang baik dalam perencanaan, logistik, operasional, personel dan keuangan dan kerjasama tersebut harus terus dibina dan dikembangkan sehingga tidak berjalan sendiri-sendiri sehingga dapat mendukung keberhasilan pendidikan secara optimal.

Permasalahan yang dihadapi oleh guru militer Akademi TNI adalah kompetensi guru militer yaitu masih rendahnya tingkat pendidikan sehingga belum mampu mendapatkan prestasi kerja yang optimal. Hal ini cenderung menurunkan akreditasi lulusan Taruna/Taruni Akademi TNI dengan gelar Sarjana Science Pertahanan atau S.T.Han sehingga hanya mampu meraih akreditasi " $\mathrm{C}$ ".

Berkaitan dengan hal tersebut di atas, beban kerja guru militer sangat menentukan peningkatan prestasi kerja sehingga mampu untuk melakukan pembenahan pada seluruh aspek terutama sistem birokrasi menuju lembaga pendidikan yang profesional, maka kompetensi dan beban kerja dapat membuat prestasi kerja guru militer menjadi lebih baik dan positif. Kompetensi merefleksikan adanya kemampuan pada setiap guru militer dalam pencapaian tujuan pendidikan, dan beban kerja mencakup seluruh elemen tugas pokok guru militer sesuai profesinya. Berdasarkan hal tersebut di atas, maka peneliti tertarik melakukan penelitian apakah terdapat hubungan kompetensi dan beban kerja dengan prestasi kerja guru militer Akademi TNI di Resimen Chandradimuka Magelang Jawa-Tenggah.

\section{Prestasi Kerja}

Salah satu indikator manusia berkualitas adalah manusia yang mempunyai prestasi kerja tinggi karena manusia yang mempunyai prestasi kerja tinggi tentu sangat diperlukan di berbagai organisasi/lembaga baik swasta maupun pemerintah, Prestasi kerja/job performance merupakan bagian penting dari proses manajemen kinerja, secara tradisional penilaian terhadap prestasi kerja harus dilakukan secara rutin dan kontinu oleh atasan, tetapi seringkali ditemui proses penilaian tersebut hanya bersifat administratif dan cenderung subjektif yang kurang memiliki daya beda yang valid. 
Kegiatan penilaian harus menjadi kegiatan strategis perusahaan karena sistem penilaian terhadap prestasi kerja harus dipandang sebagai strategi pendorong kemajuan perusahaan dan mengembangkan karyawan serta dipandang untuk melindungi hakhak karyawan berupa kompensasi/reward sehingga dapat diukur sejauh mana kewajiban dan tanggung jawab karyawan yang telah dilaksanakan, "the increase in service jobs has number of implications for job performance".

Peningkatan prestasi kerja guru militer merupakan hal yang diinginkan baik dari pihak lembaga pendidikan TNI maupun guru militer, bagi lembaga pendidikan TNI menginginkan prestasi kerja guru militer baik untuk kepentingan peningkatan hasil anak didik dan mutu lembaga pendidikan, sedangkan pada sisi lain guru militer berkepentingan untuk dapat mengembangkan diri dan mendapatkan promosi dari prestasi kerjanya, dengan peningkatan prestasi kerja tentu saja akan meningkatkan produktivitasnya oleh karena itu perlunya perbaikan sistem kerja yang dilakukan oleh setiap komponen yang ada dalam lembaga pendidikan TNI sehingga menghasilkan sebuah manajemen kinerja yang baik (performance management system), begitupun di lembaga pendidikan Tentara Nasional Indonesia (TNI).

Berdasarkan konsep dari para ahli prestasi kerja guru militer/job performance dapat disintesiskan sebagai hasil kerja yang dicapai seorang guru militer, melalui totalitas kemampuan yang dimilikinya untuk mencapai tujuan lembaga pendidikan TNI sehingga dapat mengekpresikan potensi diri dalam melaksanakan tugas sehari-hari dengan penuh rasa tanggung jawab dan semangat tinggi, dengan hasil yang sesuai dengan tujuan dan waktu kerja secara terukur.

\section{Kompetensi}

Kompetensi seseorang dapat berkembang atau meningkat melalui beberapa cara, melalui pengalaman, belajar sendiri, pendidikan formal maupun informal, Dolores Pushkar and Roe (2007:245) menyatakan, "competence has been conceptualized in terms of the features of congnitive, behavioral, and emotional functioning that comprise effective interaction with envirotment."

Kompetensi dibedakan menjadi hard dan soft kompetensi dimana untuk hard kompetensi dapat dilakukan dengan peningkatan kemampuan diri melalui pendidikan dan pengalaman sedangkan soft kompetensi adalah kompetensi yang ada pada diri manusia itu sendiri semenjak lahir. Andrew J. Elliot dan Carol S. Dweck (2005:42) menyatakan, "competence is refer to the skills and abilities a person has developed, to the degree to which the pearson is effective in her or his transaction with the environment and to how successfully a person perform." Kompetensi secara harafiah berasal dari competence yang berarti kemampuan, wewenang, dan kecakapan, dari segi etimologi, kompetensi berarti segi keunggulan, keahlian dari prilaku dan ketrampilan yang baik. Karakteristik dari kompetensi yaitu "sesuatu yang menjadi bagian dari karakter pribadi dan menjadi bagian dari prilaku seseorang dalam melaksanakan suatu tugas pekerjaan." Selanjutnya Robert A. Roe (2007:267) menyatakan, "competence is defined as ability to adquqtely perform task, duy or role, competence inttegraties knowladge skills, personal validities and attitudes."

Sifat intelektual yang harus ditunjukan dalam kompetensi adalah kemahiran, ketetapan dan keberhasilan bertindak, sifat tanggung jawab harus ditunjukkan sebagai kebenaran tindakan baik dipandang dari sudut ilmu pengetahuan, teknologi maupun etika sehingga hal ini menunjukkan seberapa besar kompetensi yang dimiliki pada tiap individu. Selanjutnya Andrew J. Elliot dan Carol S. Dweck (2005:42)) mengatakan, "competence is identical to the self-effecacy concept reviewed previously in this chapter; employe 
with strong sense of competence (or self-efficacy) believe the can execute the particular behaviors needed to achieve success at work.

Kompetensi pada hakekatnya menggambarkan pengetahuan, keterampilan, sikap dan nilai-nilai yang harus dikuasai peserta didik dan direfleksikan dalam kebiasaan berfikir dan bertindak sehingga menyebabkan suksenya suatu pekerjaan. Wesson and Granwich (2010:124) menyatakan, "competence may be defined as a condition or quality of effectiveness, ability, sufficiency, or success". Di sisi lain Becker and Ulrich (2002:105) menyatakan "competence refers to an individual knowladge, skill, ability or personalty characteristics that direcly inluence job performance." Kompetensi berasal dari kata competence yang artinya kecakapan, kemampuan dan wewenang yang mengacu pada pengetahuan (knowledge), keterampilan (skill) dan kepribadian (attitude) individu yang secara langsung mempengaruhi kinerja pegawai, selanjutnya pengertian kompetensi kerja adalah kemampuan yang dimiliki seorang pegawai dalam melakukan tindakan yang berhubungan dengan tugas dan tanggungjawab agar dapat mencapai tujuan perusahaan.

Bloom and Taxanomy (2008:345) menyatakan, "a competence is the capability to apply or use a set of realited knowladge skills and abilities require to successfully perform "crictical work fungcions" or crictical work functions or tas in deffernt work setting.

Menurut Sutrisno, Edy dkk (2012:435) mengatakan, beberapa aspek yang terkandung dalam konsep kompetensi dikemukakan, yaitu: 1). pengetahuan (knowledge), 2). pemahaman (understanding), 3). nilai (value), dan 4). kemampuan (skill). Selanjutnya hal tersebut diatas akan diuraikan satu persatu sebagai berikut: 1) Pengetahuan (knowladge) yaitu kesadaran dalam bidang kognitif, misalnya seorang pegawai mengetahui cara melakukan identifikasi belajar, dan bagaimana melakukan pembelajaran yang baik sesuai dengan kebutuhan yang ada di perusahaan, pengetahuan menurut Wibowo adalah pengetahuan yang dimiliki oleh seorang pegawai untuk melaksanakan tugas dan tanggungjawab sesuai dengan bidang atau divisi yang dikerjakannya. 2) Pemahaman (Understanding) yaitu kedalaman kognitif, dan afektif yang dimiliki oleh individu, misalnya, seorang pegawai dalam melaksanakan pembelajaran harus mempunyai pemahaman yang baik tentang karakteristik dan kondisi kerja secara efektif dan efisien. 3) Nilai (Value) adalah suatu standar perilaku yang telah diyakini dan secara psikologis telah menyatu dalam diri seseorang, misalnya, standar perilaku para pegawai dalam melaksanakan tugas (kejujuran, keterbukaan, demokratis, dan lain-lain), dan 4). Kemampuan (skill), adalah sesuatu yang dimiliki oleh individu untuk melaksanakan tugas atau pekerjaan yang dibebankan kepada pegawai, misalnya standar perilaku para pegawai dalam memilih metode kerja yang dianggap lebih efektif dan efisien.

Pada setiap karyawan harus wajib memiliki kompetensi yang diharapkan oleh sebuah perusahaan tentu saja, hal ini akan secara langsung membangun perusahaannya tersebut karena setiap orang yang memiliki kompetensi pasti memiliki kapabilitas yang terjamin jadi manager tidak usah terlalu sulit untuk memberikan perintah. Selanjutnya menurut Debrah L.Nelson dan James Campbell (2014:156), "competence refers to the relatively stable capabilities people have to performance a particular range of deffernt but realited activities."

Kompetensi menyebabkan atau memprediksi perilaku dan kinerja, criterionreferenced karena kompetensi itu benar-benar memprediksi siapa-siapa saja yang kinerjanya baik atau buruk, berdasarkan kriteria atau standar kerja tertentu selanjutnya peningkatan kompetensi dapat dilakukan dengan mengikutkan pendidikan dan pelatihan kepada karyawan baik pada jenjang formal maupun informal, pada guru 
militer peningkatan kompetensi dapat dilakukan dengan mengikutkan para guru militer melalui pendidikan pengembangan dan pendidikan spesialisasi serta kursuskursus dan penataran-penataran baik yang dilaksanakan di Mabes TNI maupun pada matra masing-masing, dengan kompetensi yang mumpuni tujuan setiap lembaga pendidikan akan dapat tercapai dengan mudah, sesuai dengan proses MSDM sebagai berikut:

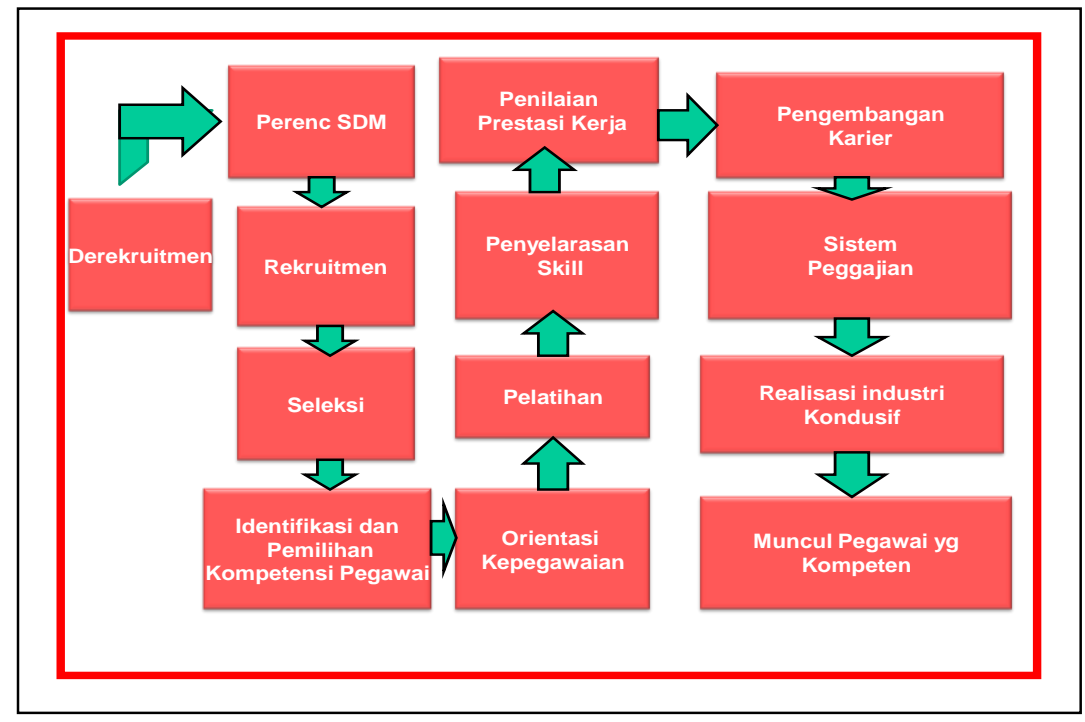

Dari beberapa definisi para ahli di atas maka kompetensi guru militer dapat disintesiskan sebagai suatu kemampuan dalam melaksanakan atau melakukan pekerjaan serta tugas yang dilandasi sepuluh komponen yaitu kepemimpinan kreativitas kemempuan merencanakan kemampuan menyatakan pendapat kemampuan memutuskan kemampuan mengawasi/mengendalikan kerjasama daya tangakap daya tanggap dan kemampuan melaksanakan tugas.

\section{Beban Kerja}

Sistem manajemen kinerja (performance management system) merupakan proses untuk mengidentifikasi, mengukur, dan mengevaluasi kinerja karyawan di perusahaan, "work processes are the activities that members of a work unit engage a given output usually the analysis reak down the task into those performed by each person in the work uni, this analysis help with design of efficient work systems by clarifying which task are necessary when the unit workload increases the unit add people, and when the work load decreases some members the unit many busy themselves with unrelated task in an effort to appear busy."

Seorang karyawan dikatakan berhasil melaksanakan pekerjaanya atau memiliki kinerja baik a pabila hasil kerja yang diperoleh lebih tinggi dari standar kinerja demikian sebaliknya seorang karyawan yang hasil pekerjaannya tidak mencapai standar pekerjaan dapat dikatakan berkinerja rendah, standar kinerja dapat ditentukan dari isi suatu pekerjaan dapat dijadikan sebagai dasar penilaian setiap pekerjaan dengan memperhatikan jumlah, kualitas, ketepatan waktu mengerjakan, kehadiran dan kemampuan bekerja sama sehingga menghasilkan suatu beban kerja. Standar kinerja juga dapat diukur berdasarkan target waktu spesifik melalui tugas pokoknya walaupun 
mungkin dimodifikasi jika muncul keadaan baru yang dirumuskan dengan luas di dalam terminologi outcome di bagian dari tanggung jawab/perumusan tugas akan tetapi perumusan harus diperluas sampai sejauh mana mungkin diperinci. Standar kinerja dapat diuat dari uraian jaatan untuk mengaitkan definisi jaatan statis ke beban kerja yang statis, standar kinerja dapat dibuat untuk setiap individu dengan berpedoman pada uraian jabatan sehingga setiap guru militer dapat mengusulkan sasaran-sasaran kepada atasan secara tertulis yang terdiri dari lima (5) hingga sepuluh (10) jabatan yang diungkap secara spesifik dan dapat diukur serta langkah-langkah untuk menyelesaikannya yang disebut sebagai beban kerja. Sasaran dari setiap beban kerja adalah kondisi atau sejumlah barang yang harus dicapai dalam kurun waktu tertentu dan dapat diukur secara kuantitatif, dalam rangka mencapai sasaran kinerja, uraian jabatan dirinci menjadi rencana tindakan kinerja yaitu tindakan dan tahapan-tahapan yang akan dilakukan, "the perceived relationship between the amount of mental processing capability or resources and the amount required by the task. The record of outcomes produced on spesfied job fungcion or activity during a specified time parade."

Akademi TNI terdiri dari unit-unit kerja termasuk Resimen Chandradimuka ada didalamnya, dimana pada unit-unit kerja terdiri dari beberapa jabatan yang tersusun dalam struktur organisasi Akademi TNI, Resimen Chandradimuka adalah bagian dari Akademi TNI yang Danmenchandra berkedudukan langsung dibawah Danjen Akademi TNI, dalam melaksanakan tugas jabatan yang ada dalam di Akademi TNI dilaksanakan berdasarkan tugas dan fungsi dari jabatan tersebut (job diskription). Informasi jabatan tersebut dimaksudkan agar dapat digunakan sebagai alas untuk menyempurnakan aparatur baik di bidang kelembagaan, ketatalaksanaan dan sumber daya manusia (SDM), standar kinerja dapat dibuat dari uraian jabatan untuk mengaitkan definisi jabatan statis ke kinerja kerja dinamis, sehingga pencapaian tujuan lembaga pendidikan tercapai secara optimal sesuai dengan visi dan misi Akademi TNI. Kepala Tim Guru Militer yang bertangung jawab langsung dibawah Danmenchandra dalam memberikan pelajaran dan pengasuhan kepada Taruna/Taruni Tingkat I, dalam struktur organisasi dapat dijabarkan berdasarkan tugas pokoknya dalam setiap jabatan dibawah kendali Katim Gumil sesuai tabel 2.2 sebagai berikut:

Tabel 1. Uraian Jabatan Guru Militer Akademi TNI

\begin{tabular}{|l|l|l|l|}
\hline No & Jabatan & DSP & Tugas dan Tanggungjawab \\
\hline 1. & $\begin{array}{l}\text { Kepala Tim Guru } \\
\text { Militer }\end{array}$ & 1 & $\begin{array}{l}\text { Menata dan mengkoordinasikan } \\
\text { tenaga pendidik baik organik } \\
\text { atau non organik serta } \\
\text { merencanakan jumlah kebutuhan }\end{array}$ \\
\hline 2. & $\begin{array}{l}\text { Perwira Sub Teknik } \\
\text { Tempur }\end{array}$ & 1 & $\begin{array}{l}\text { Menentukan referensi, } \\
\text { menyusun, mengevaluasi dan } \\
\text { menyempurnakan bahan ajar } \\
\text { yang berhubungan dengan teknik } \\
\text { tempur }\end{array}$ \\
\hline 3. & $\begin{array}{l}\text { Kepala Urusan Teknik } \\
\text { Tempur Dasar }\end{array}$ & 1 & $\begin{array}{l}\text { Membuat laporan mengajar dan } \\
\text { menyempurnakan bahan ajar }\end{array}$ \\
\hline 4. & $\begin{array}{l}\text { Kepala Urusan } \\
\text { Pengetahuan Medan }\end{array}$ & 1 & $\begin{array}{l}\text { Merencanakan kegiatan materi } \\
\text { pengajaran dan latihan ilmu } \\
\text { medan peta dan kompas (IMPK) }\end{array}$ \\
\hline
\end{tabular}




\begin{tabular}{|l|l|l|l|}
\hline 5. & $\begin{array}{l}\text { Kepala Urusan } \\
\text { Senjata Ringan }\end{array}$ & 1 & $\begin{array}{l}\text { Mengajukan kebutuhan amunisi } \\
\text { yang digunakan untuk latihan }\end{array}$ \\
\hline 6. & $\begin{array}{l}\text { Kepala Kompi } \\
\text { Demonstarsi dan } \\
\text { Latihan }\end{array}$ & 1 & $\begin{array}{l}\text { Mempersiapkan bahan ajar dalam } \\
\text { kegiatan peragaan dan } \\
\text { demonstrasi latihan }\end{array}$ \\
\hline 7. & Bintara Pelatih & 4 & $\begin{array}{l}\text { Membina dan melatih disiplin } \\
\text { para Taruna }\end{array}$ \\
\hline & Jumlah & 10 & \\
\hline
\end{tabular}

Sumber: Prosedur mekanisme Katim Gumil Akademi TNI

Pada tabel di atas bahwa Tim Gumil terdiri dari 10 personel TNI dan jabatan yang tetinggi di guru militer dijabat oleh Katim Gumil/Tih dengan pangkat Letnan Kolonel dan membawahi masing-masing kepala yang diduduki oleh Perwira dan Bintara, Katimgumil sebagai koordinator para guru militer yang merupakan personel Akademi TNI yang mendapatkan Sprin sebagai guru militer. Menurut Kementrian Aparatur Negara (Menpan, 2007) bahwa: Beban kerja adalah sekumpulan atau sejumlah kegiatan yang harus diselesikan oleh suatu unit organisasi atau pemegang jabatan dalam jangka waktu tertentu sehingga dalam pengukurannya mendapatkan efisiensi dan efektifitas kerja suatu unit organisasi atau pemegang jabatan yang dilakukan secara sistematis dengan menggunakan teknik analisis jabatan, teknik analisis beban kerja dan teknik manajemen yang dimaksudkan dengan informasi tersebut dapat digunakan sebagai alas untu meneyempurnakan aparatur baik di bidang kelembagaan, ketatalaksanaan dan sumber daya manusia (SDM). Menurut Song Jiang dan Dawson (2005), "workload is an opportunity for the employees to learn and prosper more quickly as employees do their jobs they gain more work experince, which enrich their exposure, it is also viewed that employees who have enough work to do remains more active and energic while work-less employees leftover inactive and lazy." Bagi PNS/TNI/Polri beban kerja adalah besaran pekerjaan yang harus dipikul oleh suatu jabatan/ unit organisasi dan merupakan hasil kali antara volume kerja dengan norma waktu. Menurut Permendagri tahun 2008, beban kerja merupakan salah satu teknik manajemen untuk mendapatkan informasi jabatan, melalui proses penelitian dan pengkajian yang dilakukan secara analisis. Informasi jabatan tersebut dimaksudkan agar dapat digunakan sebagai alas untuk menyempurnakan aparatur baik di bidang kelembagaan, ketatalaksanaan dan sumberdaya manusia (SDM) sebagai bahan evaluasi. Di lingkungan TNI berdasarkan Peraturan Panglima Perpang/93/XI/2011 tanggal 29 November 2011 bahwa beban kerja adalah sebuah target pekerjaan yang dikerjakan dalam satu satuan waktu tertentu yang biasa dirinci dalam hari, minggu, bulan, riwulan, semeser dan tahun.

Dari konsep beberapa ahli, maka beban kerja guru militer dapat disintesiskan sebagai sebuah target kerja/kegiatan dalam melaksanakan tugas utama/pokok, tugas rutin, tugas tambahan dan tugas limpahan yang dapat diselesaikan dalam satu satuan waktu.

\section{METODE PENELITIAN}

Metode yang digunakan dalam penelitian ini adalah suvey dengan pendekatan korelasional yang berusaha menggambarkan hubungan antar variabel. Pada penelitian ini terdapat tiga varibel yaitu dua variabel bebas dan satu variabel terikat. Kompetensi sebagai variabel $\left(X_{1}\right)$, dan beban kerja sebagai varaibel $\left(X_{2}\right)$ serta prestasi kerja sebagai varaibel (Y). Populasi terjangkau adalah guru militer Akademi TNI. scale) dengan 
sebaran skor antara 1 sampai dengan 5. Selanjutnya dilakukan uji coba instrumen untuk Data dikumpulkan dalam penelitian melalui kuesioner yang berupa skala penilaian (rating menentukan butir-butir instrumen yang valid dan reliabel. Setelah dilakukan analisis deskriptif dilanjutkan dengan uji persyaratan analisis berupa uji normalitas, uji linearitas data dan keberartian regresi. Selanjutnya dilakukan uji hipotesis dengan menggunakan teknik analisis korelasional.

\section{HASIL DAN PEMBAHASAN}

Penelitian ini terdiri dari tiga variabel, yaitu dua variabel bebas sebagai predaktor dan satu variabel terikat sebagai respon. Dua variabel bebas tersebut adalah kompetensi $\left(X_{1}\right)$ dan beban kerja $\left(X_{2}\right)$. Sedangkan variabel terikat adalah prestasi kerja $(\mathrm{Y})$. Data tersebut untuk beban kerja $\left(\mathrm{X}_{1}\right)$ dan prestasi kerja $(\mathrm{Y})$ adalah hasil kuantifikasi dari jawaban-jawaban responden terhadap kuesioner yang disebarkan, sedangkan untuk kompetensi $\left(\mathrm{X}_{2}\right)$ diperoleh dari data sekunder yaitu Dapen (daftar penilaian) yang dilaksanakan secara periodik yaitu satu semester (6) bulan sekali. Beberapa pembahasan dan interpretasi hasil penelitian di atas secara lebih mendalam dikemukakan pada uraian di bawah ini. 


\section{Hubungan Kompetensi $\left(X_{1}\right)$ dengan Prestasi Kerja $(Y)$}

Hasil pengujian hipotesis pertama dapat disimpulkan bahwa terdapat hubungan positif antara kompetensi dengan prestasi kerja, dimana koefisien korelasi sebesar 0,59 menghasilkan $t_{\text {hitung }}=5,95$ lebih besar dari $t_{\text {tabel }}=2,65$ pada $\alpha=0,01$. Kesimpulan tersebut menunjukkan bahwa semakin tinggi kompetensi, maka akan semakin tinggi pula prestasi kerja.

Korelasi antara kompetensi dengan prestasi kerja menunjukkan kebermaknannya, baik melalui korelasi product moment maupun korelasi parsial. Hasil analisis ini memberikan petunjuk bahwa kompetensi merupakan salah satu faktor utama yang berkonstribusi terhadap prestasi kerja. Dari hasil itu pula dapat diinterpretasikan bahwa peningkatan kompetensi akan memberikan konstribusi yang berarti terhadap prestasi kerja.

Hasil pengujian hipotesis menunjukkan bahwa kompetensi berhubungan positif dengan prestasi kerja guru militer Akademi TNI di Menchandra Magelang. Adanya hubungan positif kompetensi terhadap prestasi kerja menunjukkan bahwa apabila guru militer memiliki kompetensi yang tinggi dan pada penempatan yang tepat maka prestasi kerja akan semakin meningkat terhadap organisasi. Hal ini menunjukkan guru militer untuk diberdayakan dalam meningkatkan potensi diri dan kemampuannya sehingga akan meningkatkan prestasi kerja sehingga meningkatkan mutu pendidikan Taruna Tingkat I Akademi TNI. Kompetensi diupayakan oleh atasan dengan meningkatkan kemampuan dan keterampilan melalui pendidikan, pelatihan, kebebasan mengembangkan diri dan memberi promosi sehingga akan meningkatkan tanggungjawab dalam melaksanakan tugas sesuai ditentukan. Menurut M.V. Rafter (2009:24), "it is therefore important to be certain that abilities tested for really are essential to job performance or that absence of these abilities really does create a safety hazard."

Guru militer yang diberi tanggung jawab akan melaksanakan tugas dengan baik karena mendapatkan kepercayaan dari atasan dan perlunya "the right man in the right place, the right man on the right job, hasil penelitian ini memperkuat teori yang terkait dengan kompetensi yaitu, "competence as ability, although relatively little is known about whether and how motives are related to a person's skills and abilities, we suggest that the relationship can have two main forms: 1) motives may have a causal effect on the development of skills, because mastery of skill may put the individual in better position to obtain a motive-specific incentive and thus satisfy her or his notivational need, 2) motives may interact with existing skills in shaping behavior."

Hal ini sesuai dengan pendapat Ruth Kanfer dan Phillip L.A. Neckerman dalam HandBook Competence (2005:336), "job performance is inflyenced by a number of factor, including stable trait-factors internal to individual (e.g. abilities and skills) they are can development of work competencies and competence and then consider some of the other factor the expression of competence in job performance." Dolores Pushkar and Roe (2007:245) menyatakan, "competence has been conceptualized in terms of the features of congnitive, behavioral, and emotional functioning that comprise effective interaction with envirotment."

Kompetensi dibedakan menjadi hard dan soft kompetensi dimana untuk hard kompetensi dapat dilakukan dengan peningkatan kemampuan diri melalui pendidikan dan pengalaman sedangkan soft kompetensi adalah kompetensi yang ada pada diri manusia itu sendiri semenjak lahir. Andrew J. Elliot dan Carol S. Dweck (2005:42) menyatakan, "competence is refer to the skills and abilities a person has developed, to the degree to which the pearson is effective in her or his transaction with the environment and to how successfully a person perform." Kompetensi secara harafiah berasal dari competence yang berarti kemampuan, wewenang, dan kecakapan, dari segi etimologi, kompetensi berarti segi 
keunggulan, keahlian dari prilaku dan ketrampilan yang baik. Karakteristik dari kompetensi yaitu "sesuatu yang menjadi bagian dari karakter pribadi dan menjadi bagian dari prilaku seseorang dalam melaksanakan suatu tugas pekerjaan." Selanjutnya Robert A. Roe (2007:267) menyatakan, "competence is defined as ability to adquqtely perform task, duy or role, competence inttegraties knowladge skills, personal validities and attitudes." Sifat intelektual yang harus ditunjukkan dalam kompetensi adalah kemahiran, ketetapan dan keberhasilan bertindak, sifat tanggung jawab harus ditunjukkan sebagai kebenaran tindakan baik dipandang dari sudut ilmu pengetahuan, teknologi maupun etika sehingga hal ini menunjukkan seberapa besar kompetensi yang dimiliki pada tiap individu. Selanjutnya Andrew J. Elliot dan Carol S. Dweck (2005:42)) mengatakan, "competence is identical to the self-effecacy concept reviewed previously in this chapter; employe with strong sense of competence (or self-efficacy) believe the can execute the particular behaviors needed to achieve success at work. Kompetensi pada hakekatnya menggambarkan pengetahuan, keterampilan, sikap dan nilai-nilai yang harus dikuasai peserta didik dan direfleksikan dalam kebiasaan berfikir dan bertindak sehingga menyebabkan suksenya suatu pekerjaan. Wesson and Granwich (2010:124) menyatakan, "competence may be defined as a condition or quality of effectiveness, ability, sufficiency, or success". Di sisi lain Becker and Ulrich (2002:105) menyatakan "competence refers to an individual knowladge, skill, ability or personalty characteristics that direcly inluence job performance." Kompetensi berasal dari kata competence yang artinya kecakapan, kemampuan dan wewenang yang mengacu pada pengetahuan (knowledge), keterampilan (skill) dan kepribadian (attitude) individu yang secara langsung mempengaruhi kinerja pegawai, selanjutnya pengertian kompetensi kerja adalah kemampuan yang dimiliki seorang pegawai dalam melakukan tindakan yang berhubungan dengan tugas dan tanggungjawab agar dapat mencapai tujuan perusahaan.

Bloom and Taxanomy (2008:345) menyatakan, "a competence is the capability to apply or use a set of realited knowladge skills and abilities require to successfully perform "crictical work fungcions" or crictical work functions or tas in deffernt work setting. Dengan demikian, semakin baik kompetensi seseorang, maka akan semakin tinggi prestasi kerja yang dihasilkannya.

\section{Hubungan Beban Kerja dengan Prestasi Kerja}

Hasil pengujian hipotesis kedua dapat disimpulkan bahwa terdapat hubungan antara beban kerja dengan prestasi kerja, dimana koefisien korelasi sebesar 0,57 menghasilkan $t_{\text {hitung }}=5,75$ lebih besar dari $t_{\text {tabel }}=2,65$ pada $\alpha=0,01$. Kesimpulan tersebut menunjukkan bahwa semakin tinggi beban kerja, maka akan semakin tinggi pula prestasi kerja.

Korelasi antara beban kerja dengan prestasi kerja menunjukkan kebermaknannya, baik melalui korelasi product moment maupun korelasi parsial. Hasil analisis ini memberikan petunjuk bahwa beban kerja merupakan salah satu faktor utama yang berkonstribusi terhadap prestasi kerja. Dari hasil itu pula dapat diinterpretasikan bahwa peningkatan beban kerja akan memberikan konstribusi yang berarti terhadap prestasi kerja. Hal ini sesuai dengan pendapat Gerlard R Feris dan David Jelmor dalam Sari Manejemen Sumber Daya Manusia (terjemahan) bahwa penilaian beban kerja dapat mempertinggi produktivitas para pekerja tetapi harus dilaksanakan dalam satu cara sehingga meningkatkan karyawan untuk lebih produktif, sehingga dapat bersama-sama meningkatkan apa yang diputuskan pada masa mendatang. 
Mila Badriah, dalam Manajemen Sumber Daya Manusia mengatakan bahwa penilaian beban kerja PNS secara periodik memiliki tujuan untuk mengetahui prestasi kerja seorang pegawai dan untuk mengetahui kekurangan dan kelebihan yang dimiliki oleh pegawai tersebut dalam melaksanakan tugasnya dan selanjutnya penilaian tersebut digunakan sebagai bahan pertimbangan dalam pembinaan PNS antara lain dalam pengangkatan, kenaikan pangkat, pengangkatan dalam jabatan, pendidikan dan pelatihan serta memberikan penghargaan.

\section{Hubungan antara kompetensi dan Beban Kerja Secara Bersama-sama dengan Prestasi Kerja}

Hasil pengujian hipotesis ketiga dapat disimpulkan bahwa kompetensi dan beban kerja secara bersama-sama mempunyai hubungan positif dengan prestasi kerja. Koefisien korelasi ganda antara kedua variabel bebas dengan variabel terikat $R_{\mathrm{y} .12}$ sebesar 0,71 meghasilkan $F_{\text {hitung }}=33,99$ lebih besar dari $F_{\text {tabel }}=4,94$ pada $\alpha=0,01$. Dari koefisien korelasi tersebut, dapat dihitung koefisien determinasi $\left(\mathrm{R}_{\mathrm{y} .12}\right)^{2}$ sebesar 0,50 berarti bahwa $50 \%$ proporsi varians prestasi kerja dapat dijelaskan secara bersama-sama oleh kompetensi serta beban kerja.

Menurut Colquit/Le Pane/Wilsson dalam Organizational Behavior mengatakan bahwa, "employees can build their own competence by engaging in self-directed learning, seeking out feedback from their managers, and managing their own workload developt the job performance."

Ahli yang lain yaitu Dick Grote dalam The Performance Appraisal Question and Answer Book Survival Guide For Managers yang menyatakan bahwa, "there are many lists of competence each list contains dozens of trais/skills/attributes-competence- that can be picked over to identify the small number that critically important the process of an organization's performance appraisal process begins the developt job performance"

Hasil pengujian hipotesis menunjukkan bahwa kompetensi berpengaruh positif dengan prestasi kerja guru militer Akademi TNI di Menchandra Magelang. Adanya pengaruh positif beban kerja melalui kompetensi terhadap prestasi kerja menunjukkan bahwa apabila guru militer memiliki kompetensi yang tinggi didukung oleh beban kerja yang tepat maka prestasi kerja akan semakin meningkat terhadap organisasi. Beban kerja dan kompetensi secara bersama-samaberpengaruh langsung positif dengan prestasi kerja artinya kompetensi yang tinggi didukung dengan beban kerja yang sesuai tugas utama/pokoknya akan mengakibatkan peningkatan prestasi kerja. Sehingga pada dasarnya tingkat kompetensi tinggi didukung oleh beban kerja yang sesuai akan meningkatkan peningkatan prestasi kerja dalam mencapai tujuan organisasi, oleh karena itu kompetensi dan beban kerja dijadikan dasar dalam mengevaluasi kinerja prestasi. 


\section{PENUTUP}

Kesimpulan: 1) Terdapat hubungan positif antara kompetensi dengan prestasi kerja guru militer Akademi TNI hal tersebut menunjukkan bahwa semakin tinggi kompetensiguru militer akan semakin tinggi prestasi kerjanya, dimana koefisien korelasi sebesar 0,59 menghasilkan $t_{\text {hitung }}=5,95$ lebih besar dari $t_{\text {tabel }}=2,65$ pada $\alpha=0,01$, dari hasil itu pula dapat diinterpretasikan bahwa peningkatan kompetensi akan memberikan konstribusi yang berarti terhadap prestasi kerja. 2) Terdapat hubungan positif antara beban kerja dengan prestasi kerja guru militer Akademi TNI, dimana koefisien korelasi sebesar 0,57 menghasilkan $t_{\text {hitung }}=5,75$ lebih besar dari $t_{\text {tabel }}=2,65$ pada $\alpha=0,01$, dari hasil itu pula dapat diinterpretasikan bahwa peningkatan beban kerja akan memberikan konstribusi yang berarti terhadap prestasi kerja. 3) Terdapat hubungan positif kompetensi dan beban kerja secara besama-sama dengan prestasi kerja guru militer Akademi TNI.Dari koefisien korelasi tersebut, dapat dihitung koefisien determinasi $\left(\mathrm{R}_{\mathrm{y} .12}\right)^{2}$ sebesar 0,50 berarti bahwa $50 \%$ proporsi varians prestasi kerja dapat dijelaskan secara bersama-sama oleh kompetensi serta beban kerja.

Saran: Berdasarkan hasil penelitian penulis menyarankan, Kepada para peneliti adalah sebagai berikut: a.Peneliti selanjutnya disarankan untuk lebih memperdalam tentang prestasi kerja dengan menambahkan faktor-faktor selain kompetensi dan beban kerja, misalnya: prilaku organisasi, kompensasi dan motivasi.b.Penelitian selanjutnya disarankan untuk menggunakan metode lain dalam meneliti prestasi kerja, misalnya: melalui wawancara mendalam kepada para guru militer dan atasan serta bawahan sehingga mendapatkan informasi yang lebih mendalam dan bervariasi dari angket yang disebarkan kepada responden yakni guru militer.

\section{DAFTAR RUJUKAN}

A. Dale Timple, Seri Manajemen Sumber Daya Manusia, Terjemahan Seri Sumber Daya Manusia, Jakarta: Kelompok Gramedia cetakan kelima, 2002.

Andrew J. Elliot, Carol S.Dweck, Hand Book of Competence and Motivation New York: Library of Congress Cataloge, 2007 Hand Book Competence and Motivation (New York: The Guilford Press, 2005)

Bercker dan Ulrich, HRD Management Personalty. USA: Kill World, 2002

Bloom and Taxanomy, Hand Book Education Objective. USA: Grafedad Hard, 2008

Colquit/LePane/Wesson, Organizational Behavior, New York: McGraw-Hill International Edition, 2011.

Debrah L. Nelson dan James Campell Quick, Principles of Organization Behavior. SouthWestern: Thomson, 2014

Diknas, Lembaran Negara Undang-Undang Sisdiknas Nomor 20 Tahun 2003, Jakarta: Sinar Grafika, 2003. 
Dolores Pushkar dan Roe, Improving Competence Across the Lifespan New York: Kluwer Academic Publishers, 2007

Edy Sutrisno, et.al, Manajemen Sumber Daya Manusia, Jakarta: Kencana Prenada Media Group, 2012

Furqon dkk, Statistika Terapan untuk Penelitian, Bandung: Alfabeta, 2004.

Kadir, Statistika, Jakarta : Rosemata Sampoerna, 2010.

Keputusan Komandan Jenderal Akademi TNI Nomor Kep/9/VII/2012 tanggal 5 Juli 2012 tentang Peraturan Kehidupan Taruna (Perduptar) Akademi TNI.

Kep. Menpan No 20/VII/ 2007 tanggal 20 Juli 2007 tentang Penilaian Beban Kerja Aparatur

Mabes TNI, Perpang/93/XI/2011 tanggal 29 November 2011 tentang "Petunjuk Administrasi Penilaian dan Perhitungan Beban Kerja di Lingkungan Tentara Nasional Indonesia

Moeheriono, Pengukuran Kinerja Berbasis Kompetensi. Bogor: Ghalia Indonesia, 2008

Noe, Hollenbeck, Gerhart and Wright, Human Resaurces Management seri Gaining Competitive Advantage, New York: Mc Graw-Hill Companies, 2012.

Permendagri No 12/VI/2008 tanggal 12 Juni 2008 tentang penilaian beban kerja bagi PNS

Profil Seskoal, Misi Seskoal sebagai, “Center Of Excelent”, Jakarta: Seskoal 2010

Robert A. Roe, Personalty Competence. London: Quality For Competence, 2007

Stephen P.Robbins n Mary Coulter, Management, Pearson Education Limited, 2012.

Song Jiang and Dawson, "A Quantitative Models of Workload", Journal of the American No 7 th 2005

Sukardarumidi, Metodologi Penelitian, Petunjuk Praktis untuk Meneliti, Yogyakarta: Gajah Mada University Press 2004.

Siagian Sondang. Manajemen Sumber Daya Manusia, Jakarta: Bumi Aksara, 2008.

Weason dan Grenwich, Competence and Job Performance. USA: McGraw-Hill, 2010. 